\title{
The importance of sedimenting organic matter, relative to oxygen and temperature, in structuring lake profundal macroinvertebrate assemblages
}

\author{
Jussi Jyväsjärvi • Gergely Boros • \\ Roger I. Jones · Heikki Hämäläinen
}

Received: 24 May 2012/Revised: 19 November 2012/Accepted: 15 December 2012/Published online: 25 December 2012

(C) Springer Science+Business Media Dordrecht 2012

\begin{abstract}
We quantified the role of a main food resource, sedimenting organic matter (SOM), relative to oxygen (DO) and temperature (TEMP) in structuring profundal macroinvertebrate assemblages in boreal lakes. SOM from 26 basins of 11 Finnish lakes was analysed for quantity (sedimentation rates), quality ( $\mathrm{C}: \mathrm{N}: \mathrm{P}$ stoichiometry) and origin (carbon stable isotopes, $\delta^{13} \mathrm{C}$ ). Hypolimnetic oxygen and temperature were measured from each site during summer stratification. Partial canonical correspondence analysis (CCA) and partial regression analyses were used to quantify contributions of SOM, DO and TEMP to community composition and three macroinvertebrate metrics. The results suggested a major contribution of SOM in regulating the community composition and total biomass. Oxygen best explained the Shannon diversity, whereas TEMP had largest contribution to the variation of Benthic Quality Index. Community composition was most strongly related to
\end{abstract}

Handling editor: B. Oertli

J. Jyväsjärvi $(\bowtie)$ · R. I. Jones · H. Hämäläinen

Department of Biological and Environmental Science,

University of Jyväskylä, P.O. Box 35, 40014 Jyväskylä,

Finland

e-mail: jussi.p.jyvasjarvi@jyu.fi

G. Boros

Balaton Limnological Research Institute of the Hungarian Academy of Sciences, P.O. Box 35, Tihany 8237,

Hungary $\delta^{13} \mathrm{C}$ of SOM. Based on additional $\delta^{13} \mathrm{C}$ and stoichiometric analyses of chironomid taxa, marked differences were apparent in their utilization of SOM and body stoichiometry; taxa characteristic of oligotrophic conditions exhibited higher $\mathrm{C}: \mathrm{N}$ ratios and lower $\mathrm{C}: \mathrm{P}$ and $\mathrm{N}: \mathrm{P}$ ratios compared to the species typical of eutrophic lakes. The results highlight the role of SOM in regulating benthic communities and the distributions of individual species, particularly in oligotrophic systems.

Keywords Chironomid larvae · Food quality · Sediment trap · Ecological stoichiometry ·

Stable isotope analysis

\section{Introduction}

The profundal area of lakes can be characterized as the deeper water area with fine sediments, lacking illumination and therefore net primary production and rooted vegetation (Wetzel, 2001). The macroinvertebrate fauna inhabiting profundal zone is typically comprised mostly of larvae of non-biting midges (Diptera: Chironomidae), segmented worms (Annelida: Oligochaeta) and amphipod crustaceans, and is often supplemented by small mussels, water mites and non-chironomid dipteran larvae. Profundal macroinvertebrates play a key role in lake ecosystems. Most species are detritivorous and, due to high abundances, capable of processing considerable amounts of dead 
and dying organic matter sedimenting from the upper water column (Jónasson, 2004). Furthermore, many species are important prey items for predatory invertebrates and benthivorous fish (Lindegaard, 1994). Profundal macroinvertebrates have a long-standing history in lake monitoring and they are also an essential component of ecological assessment of e.g. European lakes mandated by the Water Framework Directive (WFD; European Commission, 2000).

The earliest lake classification schemes were based on profundal benthic fauna, particularly chironomids, and their empirical and perceived relationships to trophic state of lakes (see Brinkhurst, 1974 for review). Thienemann (1922) and Brundin (1951) were the first to show empirically that hypolimnetic oxygen is pivotal in structuring profundal communities. This has remained a central tenet of profundal macroinvertebrate ecology (Int Panis et al., 1996; Real et al., 2000; Verneaux et al., 2004). Appreciation of the role of phosphorus as a main driver of lake productivity and trophic state (Vollenweider, 1968; Schindler, 1974) enabled a more comprehensive understanding of pelagic-benthic coupling: anthropogenic nutrient enrichment accelerates lentic algal productivity and profundal fauna respond to the consequent increase in benthic food resources (Graf, 1989; Johnson \& Wiederholm, 1992; Goedkoop \& Johnson, 1996). Food availability has been thus a second widely presented explanation for the strong linkage between profundal communities and lake productivity (Saether, 1979; Wiederholm, 1980; Kansanen et al., 1984). In fact, it has been postulated that the relative importance of oxygen and food is dependent on the trophic status; in meso- and eutrophic lakes hypolimnetic oxygen becomes more important due to its deficiency whereas in oxygen-rich oligotrophic lakes the community structure is predominantly controlled by food availability (Saether, 1979; Jónasson, 2004). However, to our knowledge, this pattern still remains to be demonstrated empirically. Autecological studies of profundal macroinvertebrates, chironomids in particular, have suggested considerable differences in temperature optima and thus stenothermic distributions of profundal macroinvertebrate taxa (see e.g. Wiederholm, 1983; Brooks et al., 2007), implying that thermal conditions could significantly contribute also to community composition. This is supported by community-level studies suggesting that lake-bottom temperature regulates the profundal macroinvertebrate abundance and species composition (e.g. Rasmussen \& Kalff, 1987; Dinsmore et al., 1999; Jyväsjärvi et al., 2009).

The relative importance of the three suggested main drivers (oxygen, food resources and temperature) of profundal macroinvertebrate community variation is still poorly understood and thus controversial (Kansanen et al., 1984; Real \& Prat, 1992), perhaps for two main reasons. First, in most cases, profundal nutritional conditions are indirectly inferred from epilimnetic primary production, which itself is estimated by proxies like total phosphorus or chlorophyll $a$ concentration, whereas more direct measurements of quantity and quality of primary food resource-i.e. sedimenting organic matter, SOM, are rarely related to profundal fauna, and even then only within individual lakes (Lang \& Hutter, 1982; Goedkoop \& Johnson, 1996). Second, oxygen, temperature and food availability are often inter-related (Brodersen \& Anderson, 2002; Brodersen \& Quinlan, 2006), hindering evaluation of their individual contributions to macroinvertebrate community variation from observational field data.

Earlier studies have shown that profundal community structure within and among boreal lakes varies with morphometry, and with lake depth in particular (Johnson \& Wiederholm, 1989; Hynynen et al., 1999; Jyväsjärvi et al., 2009). This is not surprising as lake morphometry effectively integrates variation in hypolimnetic oxygen and thermal conditions. Moreover, quantity and quality of SOM is partially controlled by the size and shape of the lake basin. In the sediment focusing process (Likens \& Davis, 1975; Hilton et al., 1986), resuspended material originating from shallower zones is transported into deeper parts of the basin (i.e. accumulation zones, see Håkanson, 1981) and the extent of this process is largely dependent on lake morphometry (Kamp-Nielsen \& Hargrave, 1978; Blais \& Kalff, 1995). Furthermore, the degree of microbial mineralization of SOM is expected to increase with depth resulting in more complete decomposition in deeper lakes (Jewell \& McCarty, 1971). Not only quantity but also elemental composition (i.e. quality) of the SOM likely varies with depth as nitrogen-containing proteinaceous compounds are mineralized more rapidly than carbohydrate compounds during the sedimentation process (Molongoski \& Klug, 1980; Gálvez et al., 1991; Andersen \& Jensen, 1992). Moreover, many studies have reported 
a pronounced enrichment of phosphorus $(\mathrm{P})$ of seston during sedimentation (Gálvez et al., 1991; GarciaRuiz et al., 2001; Hudson \& Taylor, 2005). This phenomenon is not only mainly a result of relatively slow decrease of phosphorus content compared to carbon (C) and nitrogen (N) (Gálvez et al., 1991) but also due to physico-chemical or bacterial $\mathrm{P}$ incorporation into the descending SOM (Garcia-Ruiz et al., 2001; Bloesch, 2004). Such alteration of SOM during the sedimentation process with depth might significantly contribute to the quantitative and qualitative variation in food resources for the profundal fauna both within and among lakes.

A fundamental concept of ecological stoichiometry, a study of elemental balance in organisms, is that a difference in the elemental ratios (C:N:P) between food and consumer leads to nutritional imbalance in the consumer, negatively affecting the individual growth and survival (Sterner \& Elser, 2002). As the optimal nutrient stoichiometry is considered to be species-specific (e.g. Elser, 2006), elemental composition of the available food can affect species distributions, and thereby modify community composition. However, despite the great attention that ecological stoichiometry has received in the scientific literature during the last decade or so, evidence for the role of food resource stoichiometry in structuring consumer communities is still weak.

Compared to the streams or littoral zone of lakes, the profundal area of each lake basin is assumingly nutritionally very homogeneous environment therefore providing an ideal habitat for testing the contribution of changing resource stoichiometry to macroinvertebrate community structure. Due to the varying nutrient status of lakes, profundal area of given lake may therefore provide optimal nutritional conditions for only few species at a time, and be inferior to other species with contrasting nutritional requirements. Thus, we could expect among-taxa differences in body C:N:P stoichiometry and, presumably, an association of body stoichiometry and trophic preference of the corresponding species (Dang et al., 2009).

Our primary aim in this study was to assess the role of quantity and quality of sedimenting organic matter in relation to hypolimnetic temperature and dissolved oxygen in controlling variation of autumnal profundal macroinverterbrate community. Using sediment traps, we collected SOM from 26 discrete basins of 11 boreal lakes to measure the quantity (input of organic matter and elements), quality (C:N:P stoichiometry) and origin (inferred from carbon stable isotope values) of SOM. We related the community variation to these factors and attempted to discriminate the effects of SOM, oxygen and temperature by partial analyses. Furthermore, we determined C:N:P stoichiometry and carbon stable isotope values of a number of chironomid indicator taxa in order to assess if the nutrient stoichiometry is species-specific and correlates with the known ecological preferences of the species.

\section{Materials and methods}

Study lakes

Sedimenting organic material and profundal macroinvertebrates were collected from 26 separate basins of 11 dimictic central and eastern Finnish lakes in 2005 or 2008 (13 basins in each year, see Table 1). The dataset comprises lakes with varying human disturbance and covers most of the macroinvertebrate assemblage (Jyväsjärvi et al., 2009) and environmental (Simola \& Arvola, 2005) variation among Finnish lakes (Table 1). By sampling 2-5 sub-basins with varying morphometry from the 6 study lakes (Table 1), we aimed also to encompass within-lake variation of macroinvertebrate assemblages and their environment. The sub-basins were considered individual basins, as they were generally distant (mean distance between sampling sites $5.7 \mathrm{~km}$ ), and in cases of proximity were clearly separated by shoals.

\section{Sediment trap data}

Sedimenting organic matter was collected using sediment traps deployed in the deepest point of each study basin. A plastic crate $(39 \times 30 \times 26 \mathrm{~cm})$ was used as a stand for two or four cylinder shape plastic collector tubes (empty tennis ball tubes, height $28 \mathrm{~cm}$, diameter $7 \mathrm{~cm}$ ), which were fastened to the corners of the crate with elastic bands. The traps were deployed at $1.5 \mathrm{~m}$ above the lake bottom to prevent contamination by resuspended sediment. Two cylindrical polyurethane pontoons were attached to opposite ends of the crate to stabilize the position and maintain the buoyancy of the trap. A heavy anchor was used to keep the traps stationary. To prevent possible 
Table 1 Geographical coordinates and morphometric and physico-chemical characteristics of the study lakes and basins

\begin{tabular}{|c|c|c|c|c|c|c|c|c|c|c|}
\hline Lake, basin & Abbr. & Lat & Lon & $\begin{array}{l}\text { Lake area } \\
\left(\mathrm{km}^{2}\right)\end{array}$ & $\begin{array}{l}\text { Sampling } \\
\text { depth (m) }\end{array}$ & $\begin{array}{l}\text { Lake mean } \\
\text { depth }(\mathrm{m})\end{array}$ & $\begin{array}{l}\text { Colour } \\
\left(\mathrm{mg} \mathrm{Pt} 1^{-1}\right)\end{array}$ & 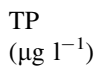 & $\begin{array}{l}\mathrm{TEMP}^{\mathrm{c}} \\
\left({ }^{\circ} \mathrm{C}\right)\end{array}$ & $\begin{array}{l}\mathrm{DO}^{\mathrm{c}} \\
\left(\mathrm{mg} \mathrm{l}^{-1}\right)\end{array}$ \\
\hline Päijänne, basin $\mathrm{I}^{\mathrm{b}}$ & Päil & 62.22 & 25.83 & $1,118.0$ & 33 & 16.2 & 54 & 17 & 8.1 & 3.9 \\
\hline Päijänne, basin II $^{\mathrm{b}}$ & Päi2 & 62.16 & 25.83 & $1,118.0$ & 45 & 16.2 & 54 & 17 & 7.4 & 9.2 \\
\hline Päijänne, basin III $^{\mathrm{b}}$ & Päi3 & 62.07 & 25.77 & $1,118.0$ & 80 & 16.2 & 54 & 10 & 5.7 & 11.3 \\
\hline Jyväsjärvi basin $\mathrm{I}^{\mathrm{b}}$ & Jyv1 & 62.23 & 25.73 & 3.3 & 8 & 5.7 & 60 & 23 & 15.7 & 8.5 \\
\hline Jyväsjärvi, basin II $^{\mathrm{b}}$ & Jyv2 & 62.23 & 25.75 & 3.3 & 15 & 5.7 & 60 & 23 & 15.7 & 5.7 \\
\hline Jyväsjärvi basin III ${ }^{\mathrm{a}}$ & Jyv3 & 62.24 & 25.78 & 3.3 & 23 & 5.7 & 60 & 26 & 16 & 5.6 \\
\hline Muuratjärvi, basin $\mathrm{I}^{\mathrm{b}}$ & Muu1 & 62.11 & 25.53 & 31.5 & 17 & 13.5 & 40 & 14 & 5.6 & 2.2 \\
\hline Muuratjärvi, basin II $^{\mathrm{b}}$ & Muu2 & 62.12 & 25.59 & 31.5 & 27 & 13.5 & 40 & 6 & 7.7 & 10.3 \\
\hline Muuratjärvi, basin III $^{\mathrm{b}}$ & Muu3 & 62.14 & 25.55 & 31.5 & 42 & 13.5 & 40 & 6 & 7.7 & 11.2 \\
\hline Isojärvi, basin $\mathrm{I}^{\mathrm{a}}$ & Iso1 & 61.65 & 25.12 & 18.3 & 24 & 16.4 & 15 & 5 & 8.3 & 5.5 \\
\hline Isojärvi, basin $\mathrm{II}^{\mathrm{a}}$ & Iso2 & 61.69 & 25.07 & 18.3 & 25 & 16.4 & 20 & 4 & 8.3 & 9.3 \\
\hline Isojärvi, basin III $^{\mathrm{a}}$ & Iso3 & 61.66 & 25.16 & 18.3 & 44 & 16.4 & 15 & 3 & 5.2 & 10.8 \\
\hline Isojärvi, basin $\mathrm{IV}^{\mathrm{a}}$ & Iso4 & 61.71 & 25.02 & 18.3 & 53 & 16.4 & 15 & 5 & 6.2 & 9.7 \\
\hline Isojärvi, basin $\mathrm{V}^{\mathrm{a}}$ & Iso5 & 61.72 & 24.95 & 18.3 & 64 & 16.4 & 20 & 4 & 5.5 & 10.7 \\
\hline Armisvesi, basin $\mathrm{I}^{\mathrm{a}}$ & Arm1 & 62.38 & 26.58 & 23.4 & 12 & 6.7 & 20 & 6 & 14.4 & 9.3 \\
\hline Armisvesi, basin II $^{\mathrm{a}}$ & Arm2 & 62.47 & 26.60 & 23.4 & 15 & 6.7 & 20 & 7 & 14.2 & 8.7 \\
\hline Armisvesi, basin III $^{\mathrm{a}}$ & Arm3 & 62.45 & 26.52 & 23.4 & 16 & 6.7 & 30 & 6 & 8.9 & 0.5 \\
\hline Armisvesi, basin IV $^{\mathrm{a}}$ & Arm4 & 62.45 & 26.60 & 23.4 & 24 & 6.7 & 25 & 7 & 9.6 & 4.3 \\
\hline Armisvesi, basin $\mathrm{V}^{\mathrm{a}}$ & Arm5 & 62.43 & 26.52 & 23.4 & 36 & 6.7 & 20 & 6 & 6.9 & 5.0 \\
\hline Pääjärvi, southern Finland, b. I ${ }^{\mathrm{a}}$ & PäL1 & 61.06 & 25.13 & 13.8 & 80 & 13.8 & 84 & 15 & 5.1 & 8.9 \\
\hline Pääjärvi, southern Finland, b. II $^{\mathrm{a}}$ & PäL2 & 61.05 & 25.09 & 13.8 & 20 & 13.8 & 84 & 15 & 10 & 7.0 \\
\hline Pääjärvi, central Finland ${ }^{\mathrm{b}}$ & PäK & 62.84 & 24.82 & 29.5 & 15 & 3.8 & 140 & 36 & 15.3 & 8.4 \\
\hline Saarijärvi $^{\mathrm{b}}$ & Saa & 62.72 & 25.18 & 14.1 & 25 & 5.0 & 120 & 22 & 8.7 & 4.1 \\
\hline Pyhäjärvi $^{\text {b }}$ & Pyh & 62.73 & 25.43 & 58.9 & 43 & 9.7 & 20 & 5 & 8.5 & 8.8 \\
\hline Kuorinka $^{\mathrm{b}}$ & Kuo & 62.62 & 29.40 & 13.0 & 31 & 10.0 & 4 & 3 & 7.3 & 6.7 \\
\hline Kermajärvib $^{b}$ & Ker & 62.44 & 28.64 & 85.6 & 50 & 10.1 & 17 & 6 & 8.2 & 9.9 \\
\hline
\end{tabular}

More detailed explanations on characteristics are given in the "Materials and methods" section

a Sampled in 2005

b Sampled in 2008

c Measured from hypolimnion in August

contamination from rope-attached epilimnetic algae, the assistant float was attached below the productive layer of the water column (ca. $7 \mathrm{~m}$ ) and the upper part of the rope was drawn ca. $7 \mathrm{~m}$ aside using an additional anchor (see Håkanson, 1976).

The traps were deployed in late August and removed after 26-30 days. The collector tubes were sealed with lids and stored in the dark at $5^{\circ} \mathrm{C}$ for $12 \mathrm{~h}$. The collected matter was flushed through a $250 \mu \mathrm{m}$ mesh-size sieve to remove freely swimming macroinvertebrates (e.g. Chaoborus larvae) and larger zooplankton. The material was then allowed to settle for $24 \mathrm{~h}$ and after siphoning of the overlying water, the samples were stored in preweighed plastic vials
(50 ml), lyophilized for $72 \mathrm{~h}$ and reweighed to determine the dry weight $\left(\mathrm{g} \mathrm{m}^{-2}\right.$ day $\left.^{-1}\right)$ of collected material in each collector tube.

Prior to further analyses, collected dry matter was pooled into a single sample and homogenized into a fine powder using mortar and pestle. The proportion of organic matter (loss on ignition; \% LOI) was determined by weighing a single sub-sample $(\sim 20 \mathrm{mg})$ of collected material before and after combustion at $550^{\circ} \mathrm{C}$ for $3 \mathrm{~h}$. The proportions of carbon $(\mathrm{C} \%)$ and nitrogen $(\mathrm{N} \%)$ as well as stable isotope ratios of carbon $\left(\delta^{13} \mathrm{C}\right)$ were determined as duplicates using a FlashEA 1112 elemental analyser coupled to a Thermo Finnigan DELTA ${ }^{\text {plus }}$ Advantage mass spectrometer. 
Citrus leaves were used as internal working standards, which were inserted in each run after every 10 samples. Internal precision (SD) for replicate standards was always less than $0.3 \%$. Stable isotope ratios are expressed as parts per thousand (\%o) delta values $\left(\delta^{13} \mathrm{C}\right)$ referred to the international standard (PeeDee Belemnite). Total phosphorus content (P \%) was measured as triplicates from the preweighed subsamples (ca. $12 \mathrm{mg}$ ) of sediment trap material. Samples were digested for $3 \mathrm{~h}$ in autoclave tubes at two bar pressure and at $120^{\circ} \mathrm{C}$ temperature. For digestion, we used a mixture of potassium persulfate and sulphuric acid (Grasshoff et al., 1983). After this procedure, the liberated phosphate ions were measured spectrophotometrically using the ammonium molybdate method (Strickland \& Parsons, 1972; Mackereth et al., 1978). The stoichiometric ratios of carbon, nitrogen and phosphorus (C:N:P) were calculated based on their molar units. The sedimentation rates $\left(\mathrm{g} \mathrm{m}^{-2} \mathrm{day}^{-1}\right.$, hereafter input) of organic matter (OM), C, N and $\mathrm{P}$ were calculated from their proportional contributions to the total sedimentation.

\section{Macroinvertebrate data}

Quantitative profundal macroinvertebrate samples accordant to Finnish standard (SFS 5076, 1989) were taken from the 26 study basins in late September after removal of the sediment traps. Six Ekman grab (sampling area of $234 \mathrm{~cm}^{2}$ ) replicates were hauled per site, the soft sediment material was passed through a standard $500-\mu \mathrm{m}$ sieve in the field and the retained material was preserved in $70 \%$ ethanol. In the laboratory, all animals were sorted from other material on a well-illuminated white dish. Within next 2 months, wet weights ( $g$ ) of macroinvertebrate groups (Chironomidae, Oligochaeta, Chaoboridae, Bivalvia, Acari, Crustacea and Ceratopogonidae) were weighed with an accuracy of $0.1 \mathrm{mg}$ according to Finnish standard (SFS 5076, 1989). This was done after soaking animals $10 \mathrm{~min}$ in tap water to avoid the effect of vaporization of the preservative. Wet weights were summed and converted to represent total biomass per unit area $\left(\mathrm{g} \mathrm{m}^{-2}\right)$. If necessary, head capsules of chironomid larvae, whole oligochaetes and sub-samples of chaoborid larvae were mounted on microscope slides for identification and the animals were identified to the lowest possible taxonomic level and counted. After the identification, the replicates were pooled to one sample for each basin and the counts were converted to densities (ind. $\mathrm{m}^{-2}$ ).

Supplementary macroinvertebrate samples were taken in 2008 from the 13 study basins then studied, to evaluate the variation of stable isotope signatures and stoichiometric ratios within and among chironomid taxa with varying ecological niches (Saether, 1979; Wiederholm, 1980). Specifically, we attempted to obtain specimens of species with contrasting perceived preferences of trophic status of the lake (Benthic Quality Index indicator taxa in particular, see below). After sampling, living chironomid larvae were kept overnight in clean water to allow gut clearance. After $24 \mathrm{~h}$, head capsules of the larvae were dissected and mounted on microscope slides for later identification. The abdomens were individually dried at $62^{\circ} \mathrm{C}$. The taxa collected varied among sites, and the number of samples (sites) obtained per taxa varied from 1 (Paracladopelma nigritula [Goetghebuer] and Chironomus salinarius t.) to 6 (Chironomus anthracinus [Zett.]). For each lake and species, all available specimens ranging from 1 to 10 were pooled to form a sample, due to small size of many chironomids, the material obtained was insufficient for replicate analyses. After homogenization, the pooled samples were analysed without replicates for C, N, P and stable isotope ratios of $\mathrm{C}$ using the methods described above with the exception that pike (Esox lucius L.) white muscle was used as internal standard, appropriate for animal tissue, for stable isotope analyses of chironomid larvae.

\section{Environmental data}

The water chemistry and morphometric data for each macroinvertebrate sampling site were compiled from two separate databases maintained by the Finnish environment authorities and the University of Jyväskylä (Table 1). Water colour (mg Pt $\mathrm{l}^{-1}$ ) and total phosphorus concentrations $\left(\mathrm{TP}, \mu \mathrm{g} \mathrm{l^{-1 }}\right.$ ) are based either on single-standard epilimnetic (0-2 m) measurements or are mean values of two or four measurements (Jyv3) from the summer stratification period (August) from which time consistent data were available for all sites for the year of macroinvertebrate sampling. Nutrient data from a proximate connected basin were used for three sites (Muu II, Jyv I and Pää II; see Table 1) due to lack of site-specific data in these cases. Hypolimnetic dissolved oxygen concentration (DO, $\mathrm{mg}^{-1}$ ) and water temperature (TEMP, ${ }^{\circ} \mathrm{C}$ ) were measured ca. $1 \mathrm{~m}$ above the lake 
bottom in each site using a portable dissolved oxygen meter $\left(\right.$ YSI $^{\circledR}$, model 58). These measurements were taken in late August during the strongest stratification period with minimum hypolimnetic oxygen and maximum temperature, which, rather than (assumingly quite invariable) ambient conditions during autumn overturn, we considered decisive for the autumnal macroinvertebrate assemblages.

\section{Macroinvertebrate metrics}

We applied three widely used metrics to characterize the profundal macroinvertebrate assemblages. First, abundance of the profundal fauna was quantified by total biomass (TB, see above). Second, the Shannon index $\left(H^{\prime}\right)$ was used as a measure of diversity (Shannon \& Weaver, 1949). Third, the widely used profundal community metric, Benthic Quality Index (BQI; Wiederholm, 1980), was used to assess the 'ecological status' of the chironomid assemblages (Rask et al., 2011; Jyväsjärvi et al., 2012). BQI is based on the relative abundances of seven chironomid species or genera, which are scored by integers from 1 (eutrophic species) to 5 (oligotrophic) according to their perceived preference along a lake trophy gradient. BQI was calculated for each site from the pooled macroinvertebrate samples as the abundanceweighted average of taxon scores $k_{i}$ :

$\mathrm{BQI}=\sum_{i=0}^{7} \frac{n_{i} k_{i}}{N}$,

where $k_{i}$ is the score for each indicator taxon $i, n_{i}$ is the numerical abundance of taxon $i$ and $N$ is the sum of $n_{i}$. The indicator taxa included with their corresponding scores are Chironomus plumosus L. $(k=1)$, Chironomus anthracinus (2), Sergentia coracina (Zett.) (3), Stictochironomus rosenschoeldi (Zett.) (3), Micropsectra spp. (4), Paracladopelma spp. (4) and Heterotrissocladius subpilosus (Kieffer) (5). Number of BQI indicator larvae per site varied between 0 and 39. Four sites with no indicator taxa present (Muu1, Muu2, Iso4 and Iso5) were excluded from the statistical analyses of BQI data (see Jyväsjärvi et al., 2010).

\section{Statistical analyses}

The dimensionality of multiple measures of SOM (Total sedimentation, \% LOI, inputs of OM, C, N, and
$\mathrm{P}, \mathrm{C} \%, \mathrm{~N} \%$ and $\mathrm{P} \%$ and their ratios [C:N, C:P, N:P]) was reduced using principal component analysis (PCA). As we did not have a priori information on the importance of the measured variables, they all were included in the PCA. The variables with a nonnormal distribution were normalized using either $X^{0.1}$ —or arcsine(SQRT) — transformation. A brokenstick model (see Jackson, 1993) was applied to choose the appropriate number of PCs (hereafter collectively termed as "SOM") for the subsequent analyses to represent the quantitative and qualitative variation of SOM.

Linear multiple regression analyses were applied to test the relationships between univariate community metrics (Shannon $H^{\prime}$, TB and BQI) and SOM, TEMP and DO. The distributions of the latter two were highly skewed and these variables were thus normalized using $X^{0.1}$-transformation. All possible variable subsets were evaluated and of final models were selected based on Akaike's information criterion (AIC). In addition, we used partial regression analysis (Legendre \& Legendre, 1998) to quantify the unique and shared proportion of explained variance by each variable group (i.e. SOM, TEMP, DO).

We used detrended correspondence analysis (DCA) (Hill \& Gauch, 1980) on log-transformed $\left(\log _{10}[X+\right.$ 1]) species abundance (ind. $\mathrm{m}^{-2}$ ) data to reveal the primary macroinvertebrate community patterns among the study sites. As the results of DCA suggested a unimodal model for the species data (first axis gradient length $=5.12$ standard deviation [SD] units; see ter Braak \& Prentice, 1988), we used canonical correspondence analysis (CCA) to assess the relationships between environmental variable 'groups' (SOM, TEMP, DO) and macroinvertebrate assemblages. CCA is a direct gradient analysis in which the ordination axes are constrained to be linear combinations of the environmental variables so as to maximize the species-environment relationships (ter Braak, 1986). As above, species data and environmental variables with skewed distributions were $\log _{10}$ and $X^{0.1}$-transformed, respectively. More specifically, a partial canonical correspondence analysis (pCCA) with Monte Carlo permutation test (9999 permutations) was used to quantify the individual contributions of TEMP, DO and SOM (Borcard et al., 1992; Økland \& Eilertsen, 1994; Jyväsjärvi et al., 2009). First, the total explicable variation was determined using all predictors as constraining variables. Then the 
total explained variation was partitioned among the three variable groups using one group at a time as a constraining variable and the two other groups as covariates. From the results of these runs, the fractions of community variance (unexplained, shared between the predictor variable groups, and unique to each group) were calculated according to Økland \& Eilertsen (1994). All the multivariate analyses were performed using the vegan-package (Oksanen et al., 2008) designed for the R-program (R Development Core Team, 2008).

To test the hypothesis that sedimenting organic matter might play a more important role in structuring of macroinvertebrate communities of nutrient-poor lakes, the data were roughly divided into oligotrophic (total phosphorus concentration (TP) $<10 \mu \mathrm{g} \mathrm{l}^{-1}$; $n=15)$ and eu-/mesotrophic (TP $>10 \mu \mathrm{g} \mathrm{l}^{-1}$; $n=11)$ sites based on a standard classification scheme (OECD, 1982). For both categories of lakes (Trophic class), we first fitted linear regression models using site scores of first DCA axis (i.e. community variance) as dependent variable and measures of SOM quantity and quality as independent variables. We further tested the influence of trophic class by linear models including the Trophic class (as a dummy variable) and each SOM variable in turn, together with their interaction as predictors. Both Trophic class and SOM variables were centred prior to analyses to reduce collinearity among predictors and to improve interpretability of coefficients (see e.g. Schielzeth, 2010).

\section{Results}

Macroinvertebrate and sedimentation data

Macroinvertebrate samples from the 26 sites comprised in total 1,642 individuals which were identified to 37 taxonomic units. Larvae of non-biting midges (Chironomidae) constituted a major proportion (59\%) of all taxa, while the non-chironomid assemblages were composed of oligochaetes, Pisidium and Sphaerium mussels, larvae of the phantom midge Chaoborus flavicans (Meigen) and Ceratopogonidae, crustaceans (Monoporeia affinis [Lindström], Pallasea quadrispinosa Sars and Mysis relicta Lovén), and water mites (Acari, Hydrachnellae). The four most commonly encountered taxa were the oligochaete worms
Potamothrix hammoniensis/Tubifex tubifex (occurred at 19 sites), the chironomid Procladius spp. (15 sites), Pisidium spp. (11 sites) and C. flavicans (11 sites).

The sediment trap data are summarized in Table 2. PCA generated three latent components which, based on the broken-stick model, contained more information than expected by chance. The first component (PC 1) explained $54 \%$ of the sedimentation data and nine out of $12 \mathrm{SOM}$ variables were loaded to the first component (Table 3). The two subsequent components (PC 2 and PC 3) increased the explained variance by 21.8 and $13.8 \%$, respectively, and correlated with $\mathrm{C}$ input and $\mathrm{C}: \mathrm{N}$ ratio (PC 2) and phosphorus content (PC 3) (Table 3). Characteristics of the SOM (PCs 1-3) varied relatively independently of epilimnetic total phosphorus concentration, hypolimnetic temperature and bottom oxygen concentration (Table 4). Bottom temperature showed a weak positive correlation with total phosphorus concentration of the study basin (Table 4).

Community analyses

According to DCA, the total inertia of the species data was 4.60. Eigenvalues for the first three axes were $0.62,0.32$ and 0.26 , representing gradient lengths of 5.12, 2.54 and $2.60 \mathrm{SD}$ units, respectively. The strikingly long first axis suggested a complete compositional turnover and unimodal species responses along the gradient. First, DCA axis represented the nutrient/temperature/morphometry gradient as shallow and eutrophic basins with high hypolimnetic water temperature were positioned on the left section and deep oligotrophic sites on the opposite side of the ordination plane (Fig. 1a). Consequently, the site scores of DCA axis 1 correlated strongly with TEMP (Pearson $r=-0.73)$, DO $(r=0.53)$, total phosphorus concentration $(r=-0.66)$ and sampling depth $(r=0.73)$. Accordingly, the taxa preferring eutrophic (e.g. Chironomus plumosus, C. flavicans), mesotrophic (e.g. Sergentia coracina, Spirosperma ferox Eisen) and oligotrophic (Heterotrissocladius subpilosus, Lamprodrilus isoporus Michaelsen) conditions were positioned on the left, middle and right part of the ordination plane, respectively (Fig. 1b).

Variance inflation factors (VIF) of the predictor variables ranged between 1.00 (PC 2) and 1.52 (TEMP), indicating negligible multicollinearity among the explanatory variables included in the CCA model. The 
Table 2 Basin-specific mean ( \pm SD) quantities, qualities and carbon isotopic signatures of sedimenting matter

\begin{tabular}{|c|c|c|c|c|c|c|c|c|c|c|}
\hline Site & $\begin{array}{l}\text { Total input } \\
\left(\mathrm{g} \mathrm{m}^{-2} \text { day }^{-1}\right)\end{array}$ & $\begin{array}{l}\text { OM input } \\
\left(\mathrm{g} \mathrm{m}^{-2} \text { day }^{-1}\right)\end{array}$ & LOI $(\%)$ & $\mathrm{C}(\%)$ & $\mathrm{N}(\%)$ & $\mathrm{P}(\%)$ & $\mathrm{C}: \mathrm{N}$ & $\mathrm{C}: \mathrm{P}$ & $\mathrm{N}: \mathrm{P}$ & $\delta^{13} \mathrm{C}(\%)$ \\
\hline Päi $1^{\text {b }}$ & $18.8 \pm 0.94$ & $1.7 \pm 0.09$ & 9.1 & $2.3 \pm 0.03$ & $0.5 \pm 0.003$ & $0.06 \pm 0.006$ & 5.1 & 105.3 & 20.8 & $-30.7 \pm 0.02$ \\
\hline Päi $2^{\text {b }}$ & $3.4 \pm 0.08$ & $0.4 \pm 0.01$ & 12.1 & $3.5 \pm 0.07$ & $0.7 \pm 0.011$ & $0.08 \pm 0.011$ & 6.0 & 109.5 & 18.2 & $-30.3 \pm 0.13$ \\
\hline Päi3 ${ }^{\text {b }}$ & $2.0 \pm 0.05$ & $0.5 \pm 0.01$ & 24.1 & $3.3 \pm 0.02$ & $0.7 \pm 0.006$ & $0.08 \pm 0.021$ & 5.2 & 99.4 & 19.2 & $-29.9 \pm 0.02$ \\
\hline $\mathrm{Jyv} 1^{\mathrm{a}}$ & $6.4 \pm 0.92$ & $1.2 \pm 0.15$ & 18.4 & $7.0 \pm 0.01$ & $0.8 \pm 0.014$ & $0.09 \pm 0.001$ & 9.5 & 147.1 & 15.5 & $-30.7 \pm 0.01$ \\
\hline $\mathrm{Jyv} 2^{\mathrm{a}}$ & $10.7 \pm 0.28$ & $1.7 \pm 0.05$ & 16.0 & $5.6 \pm 0.07$ & $0.7 \pm 0.017$ & $0.10 \pm 0.013$ & 10.8 & 209.8 & 19.4 & $-31.3 \pm 0.11$ \\
\hline $\mathrm{Jyv}^{\mathrm{a}}$ & $26.1 \pm 0.39$ & $3.2 \pm 0.05$ & 12.1 & $3.1 \pm 0.08$ & $0.4 \pm 0.040$ & $0.14 \pm 0.009$ & 10.2 & 57.9 & 5.7 & $-29.7 \pm 0.60$ \\
\hline Muu $1^{\text {b }}$ & $2.4 \pm 0.03$ & $0.4 \pm 0.01$ & 18.5 & $6.6 \pm 0.02$ & $0.8 \pm 0.003$ & $0.08 \pm 0.025$ & 9.6 & 223.5 & 23.3 & $-29.7 \pm 0.03$ \\
\hline Muu $2^{\text {b }}$ & $0.8 \pm 0.03$ & $0.2 \pm 0.01$ & 20.6 & $7.2 \pm 0.02$ & $0.9 \pm 0.004$ & $0.07 \pm 0.010$ & 9.0 & 267.4 & 29.7 & $-28.7 \pm 0.01$ \\
\hline Muu $3^{\text {b }}$ & $0.9 \pm 0.07$ & $0.2 \pm 0.02$ & 23.5 & $6.8 \pm 0.07$ & $1.0 \pm 0.010$ & $0.06 \pm 0.010$ & 7.8 & 283.3 & 36.3 & $-28.4 \pm 0.01$ \\
\hline Iso $^{\mathrm{a}}$ & $0.6 \pm 0.06$ & $0.3 \pm 0.03$ & 44.5 & $14.9 \pm 0.44$ & $1.8 \pm 0.014$ & $0.11 \pm 0.004$ & 9.7 & 337.3 & 34.9 & $-29.2 \pm 0.03$ \\
\hline Iso $^{\mathrm{a}}$ & $0.6 \pm 0.01$ & $0.3 \pm 0.01$ & 39.7 & $12.1 \pm 0.35$ & $1.5 \pm 0.014$ & $0.11 \pm 0.027$ & 9.7 & 281.7 & 29.0 & $-27.9 \pm 0.05$ \\
\hline Iso $^{\mathrm{a}}$ & $0.2 \pm 0.08$ & $0.1 \pm 0.05$ & 59.4 & $16.0 \pm 0.68$ & $2.2 \pm 0.171$ & $0.07 \pm 0.005$ & 8.7 & 565.9 & 65.4 & $-28.0 \pm 0.09$ \\
\hline Iso $^{\mathrm{a}}$ & $0.5 \pm 0.02$ & $0.2 \pm 0.01$ & 38.0 & $12.5 \pm 0.23$ & $1.5 \pm 0.030$ & $0.10 \pm 0.009$ & 9.7 & 316.2 & 32.7 & $-28.1 \pm 0.12$ \\
\hline $\operatorname{Iso}^{\mathrm{a}}$ & $0.5 \pm 0.01$ & $0.2 \pm 0.01$ & 34.6 & $10.6 \pm 1.14$ & $1.3 \pm 0.121$ & $0.10 \pm 0.007$ & 9.7 & 276.8 & 28.6 & $-28.2 \pm 0.19$ \\
\hline $\operatorname{Arm} 1^{\mathrm{a}}$ & $2.6 \pm 0.82$ & $0.6 \pm 0.17$ & 21.4 & $6.3 \pm 0.55$ & $1.1 \pm 0.124$ & $0.08 \pm 0.010$ & 6.8 & 196.8 & 28.8 & $-30.5 \pm 0.06$ \\
\hline $\operatorname{Arm} 2^{a}$ & $3.6 \pm 0.00$ & $0.7 \pm 0.00$ & 18.7 & $5.9 \pm 0.14$ & $0.8 \pm 0.019$ & $0.05 \pm 0.007$ & 8.5 & 285.3 & 33.5 & $-29.1 \pm 0.01$ \\
\hline $\operatorname{Arm} 3^{\mathrm{a}}$ & $2.7 \pm 0.45$ & $0.6 \pm 0.09$ & 21.1 & $6.2 \pm 0.26$ & $0.9 \pm 0.035$ & $0.05 \pm 0.013$ & 8.2 & 349.9 & 42.6 & $-31.4 \pm 0.07$ \\
\hline $\operatorname{Arm} 4^{\mathrm{a}}$ & $1.6 \pm 0.05$ & $0.4 \pm 0.01$ & 22.7 & $7.0 \pm 0.12$ & $1.0 \pm 0.009$ & $0.05 \pm 0.004$ & 8.2 & 336.2 & 41.1 & $-29.8 \pm 0.24$ \\
\hline $\operatorname{Arm} 5^{\mathrm{a}}$ & $1.6 \pm 0.04$ & $0.4 \pm 0.01$ & 27.0 & $8.0 \pm 0.10$ & $1.0 \pm 0.009$ & $0.03 \pm 0.002$ & 9.0 & 729.0 & 81.2 & $-30.3 \pm 0.37$ \\
\hline PäL1 ${ }^{a}$ & $1.6 \pm 0.01$ & $0.3 \pm 0.01$ & 17.6 & $7.2 \pm 0.07$ & $0.6 \pm 0.008$ & $0.10 \pm 0.019$ & 13.9 & 188.8 & 13.6 & $-28.1 \pm 0.09$ \\
\hline PäL2 ${ }^{\mathrm{a}}$ & $1.8 \pm 0.01$ & $0.3 \pm 0.01$ & 14.9 & $6.2 \pm 0.07$ & $0.6 \pm 0.009$ & $0.06 \pm 0.009$ & 12.9 & 264.7 & 20.6 & $-27.9 \pm 0.04$ \\
\hline PäK ${ }^{\mathrm{a}}$ & $0.6 \pm 0.10$ & $0.1 \pm 0.02$ & 17.6 & $4.4 \pm 0.96$ & $0.8 \pm 0.070$ & $0.05 \pm 0.007$ & 6.7 & 223.6 & 33.6 & $-30.5 \pm 0.13$ \\
\hline $\mathrm{Saa}^{\mathrm{b}}$ & $2.6 \pm 0.13$ & $0.7 \pm 0.03$ & 25.8 & $9.2 \pm 0.03$ & $1.0 \pm 0.017$ & $0.04 \pm 0.004$ & 10.7 & 532.0 & 49.6 & $-30.5 \pm 0.21$ \\
\hline $\mathrm{Pyh}^{\mathrm{b}}$ & $0.7 \pm 0.17$ & $0.2 \pm 0.06$ & 36.3 & $9.9 \pm 3.84$ & $1.3 \pm 0.410$ & $0.08 \pm 0.014$ & 8.7 & 326.7 & 37.5 & $-27.9 \pm 0.10$ \\
\hline $\mathrm{Kuo}^{\mathrm{b}}$ & $0.9 \pm 0.05$ & $0.3 \pm 0.02$ & 34.1 & $13.5 \pm 0.07$ & $2.0 \pm 0.011$ & $0.19 \pm 0.007$ & 7.7 & 182.1 & 23.6 & $-26.7 \pm 0.16$ \\
\hline $\mathrm{Ker}^{\mathrm{b}}$ & $0.9 \pm 0.09$ & $0.3 \pm 0.03$ & 28.9 & $8.8 \pm 0.04$ & $1.3 \pm 0.006$ & $0.07 \pm 0.015$ & 8.1 & 329.4 & 40.5 & $-27.4 \pm 0.22$ \\
\hline
\end{tabular}

The standard deviations for total input and OM input and are calculated on the basis of 2 or 4 replicate sediment collector tubes, whereas the deviations of other variables indicate replicate measurement error of a single pooled sample. See Table 1 for basin abbreviations

a Two collector tubes were used

${ }^{\mathrm{b}}$ Four collector tubes were used

three predictor groups (SOM, TEMP and DO) jointly explained $25.5 \%$ of the total inertia. SOM uniquely contributed $36.6 \%$ to the total explained variance, whereas the TEMP (22\%) and in particular DO (4\%) seemed to be of lesser importance in controlling macroinvertebrate community composition (Fig. 2). The shared proportion of explained community variance was $37.5 \%$ (Fig. 2).

Total macroinvertebrate biomass (TB) varied considerably among the study sites $\left(0.002-11.169 \mathrm{~g} \mathrm{~m}^{-2}\right)$. According to AIC, TEMP and SOM were selected in the multiple linear regression model which accounted for $50.7 \%$ of the total variance of TB (Table 5). All SOM, TEMP and DO were entered in the model for the partition of the explained variance and the results emphasized the importance of SOM quantity and quality, as it explained nearly one-third $(27.1 \%)$ of the total explained variance (Fig. 2). The Shannon index $\left(H^{\prime}\right)$ among the 26 study basins ranged between 0.0 and 1.82 with a mean of 1.22 . The best regression model, which included TEMP and DO as predictor variables, explained $43.6 \%$ of the variation in $H^{\prime}$ (Table 5). Partial regression suggested a considerable contribution of DO in predicting Shannon $H^{\prime}$ (34\% of the explained variance), whereas TEMP and SOM were of lesser importance (19.8 and 11.2\%, respectively) (Fig. 2). Mean Benthic Quality Index among the 22 sites with indicator taxa present was 2.91 (range 1.23-5.00). 
Table 3 Summary of the PCA for the sediment trap data

\begin{tabular}{lrrr}
\hline & \multicolumn{1}{c}{ PC 1 } & PC 2 & \multicolumn{1}{c}{ PC 3 } \\
\hline Eigenvalue & 6.472 & 2.615 & 1.659 \\
\% variance & 53.933 & 21.792 & 13.825 \\
\% cumulative & 53.933 & 75.725 & 89.550 \\
\% LOI & $\mathbf{0 . 7 7 1}$ & 0.549 & -0.066 \\
Total sedimentation & $\mathbf{- 0 . 9 7 0}$ & -0.027 & 0.221 \\
OM input & $\mathbf{- 0 . 9 3 0}$ & 0.208 & 0.290 \\
C input & -0.614 & $\mathbf{0 . 6 9 3}$ & 0.369 \\
N input & $-\mathbf{0 . 6 8 1}$ & 0.577 & 0.364 \\
P input & $-\mathbf{0 . 9 0 5}$ & 0.413 & -0.067 \\
C \% & $\mathbf{0 . 7 4 1}$ & 0.659 & -0.050 \\
N \% & $\mathbf{0 . 7 6 1}$ & 0.553 & -0.085 \\
P \% & -0.187 & 0.615 & $-\mathbf{0 . 7 5 7}$ \\
C:N & 0.121 & $\mathbf{0 . 3 8 5}$ & 0.049 \\
C:P & $\mathbf{0 . 7 8 9}$ & 0.143 & 0.572 \\
N:P & $\mathbf{0 . 7 8 0}$ & -0.021 & 0.581 \\
\hline The &
\end{tabular}

The highest loading for each variable is shown in bold

Table 4 Correlation matrix showing Pearson correlation coefficients between epilimnetic total phosphorus, hypolimnetic temperature and oxygen and the three principal components derived from the SOM data

\begin{tabular}{lllllll}
\hline & TP & TEMP & DO & PC1 & PC2 & PC3 \\
\hline TP & 1 & $\mathbf{0 . 5 8 9}$ & -0.227 & $-\mathbf{0 . 5 4 3}$ & -0.324 & 0.017 \\
TEMP & & 1 & -0.120 & $-\mathbf{0 . 5 4 8}$ & 0.024 & 0.124 \\
DO & & & 1 & 0.342 & -0.123 & $-\mathbf{0 . 4 7 3}$ \\
PC1 & & & & 1 & 0 & 0 \\
PC2 & & & & & 1 & 0 \\
PC3 & & & & & & 1
\end{tabular}

Statistically significant correlations are shown in bold

The regression model developed for $\mathrm{BQI}$ included TEMP, SOM (PC 1) and DO as the predictors and accounted for $84.4 \%$ of the index variation (Table 5). According to partial regression analysis, TEMP contributed by far most strongly to the variation of BQI, alone explaining $31.8 \%$ of the total explained variance (Fig. 2).

Some differences were observed between meso-/ eutrophic (TP $>10 \mu \mathrm{g} \mathrm{l}^{-1}$ ) and oligotrophic basins $\left(<10 \mu \mathrm{g} \mathrm{l}^{-1}\right.$ ) when community composition (DCA 1 axis scores) was associated with measures of SOM quantity. In oligotrophic basins, DCA 1 was negatively related to the input of organic matter (Fig. 3a) and positively to the organic (\% LOI, Fig. 3b) and carbon (C \%, Fig. 3d) and nitrogen (N \%, Fig. 3e) content of the sedimenting matter. With increasing total sedimentation and decreasing organic content, the fauna characterizing oligotrophy changed towards fauna indicating mesotrophy. In contrast, macroinvertebrate assemblages of more nutrient-rich sites did not show any relationship to SOM variables (Fig. 3). However, full models suggested that the responses between trophic classes differed only for organic matter and carbon content (significant Trophic class $\times$ SOM variable interaction, Table 6). Regardless of the nutrient status, macroinvertebrate composition was not associated with $\mathrm{C}: \mathrm{N}: \mathrm{P}$ stoichiometry of SOM (Fig. 3g-i; Table 6). In contrast, the macroinvertebrate community composition showed a strong relationship to $\delta^{13} \mathrm{C}$ values with no difference between meso-/eutrophic and oligotrophic basins (Fig. 3c; Table 6).

Chironomid C:N:P stoichiometry and stable isotopic signature

Altogether, 36 chironomid samples representing 11 different taxa were obtained from the 13 sites studied in 2008. Individual larvae $(n=1-10)$ of each species from each lake were pooled to form a sample. Different taxa were present in different sites and the number of samples (sites) per species varied from 1 to 6. The samples were first analysed for the contents of $\mathrm{C}$ and $\mathrm{N}$ and isotopic signature of $\mathrm{C}$. The amount of the remaining material was sufficient to run single phosphorus analyses for only 10 chironomid samples representing 7 taxa. The means (and ranges) of chironomid larval body C:N, C:P and N:P ratios were 6.48 (4.36-9.06), $183.84(69.26-395.65)$ and 30.50 (11.47-56.16), respectively. The elemental contents of chironomids and their ratios corresponded poorly to those measured from the SOM (Pearson $r$ range $=-$ 0.32 to 0.22 ).

BQI chironomid taxa with varying trophic preferences showed markedly different body stoichiometry (Fig. 4). A consistent pattern was observed between chironomid body stoichiometry and their indicator value (BQI score) in which the taxa preferring oligotrophic conditions had higher $\mathrm{C}: \mathrm{N}$ ratios (Fig. 4a) and lower C:P (Fig. 4b) and N:P (Fig. 4c) ratios compared to eutrophic species. Chironomid $\delta^{13} \mathrm{C}$ signatures correlated with the $\delta^{13} \mathrm{C}$ of SOM $(r=0.70)$ but were consistently lower than SOM $\delta^{13} \mathrm{C}$, particularly at the lower end of the gradient 

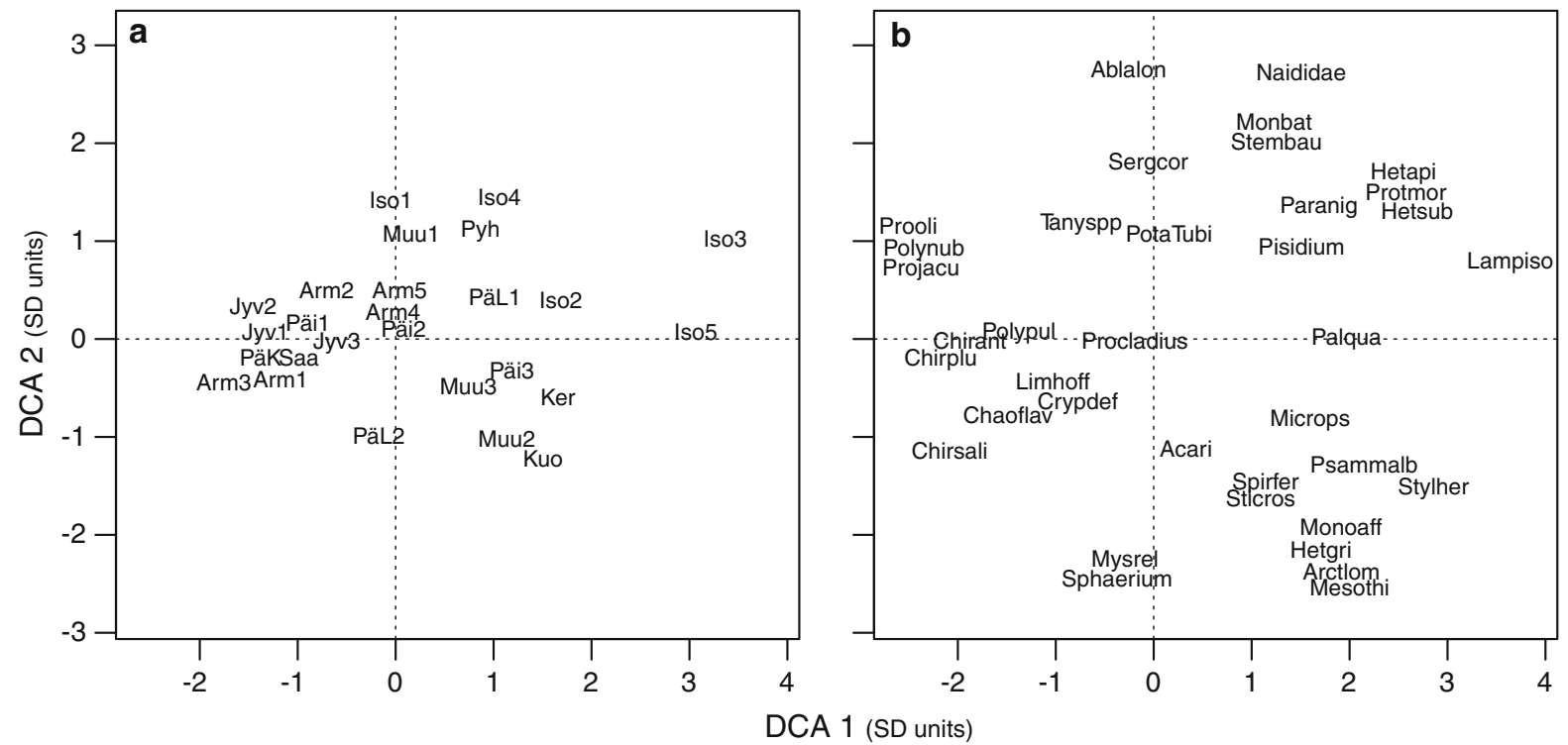

Fig. 1 Two-dimensional detrended correspondence analysis (DCA) plots displaying the basins (a) and taxa (b). See Table 1 for the abbreviations of study basins. The abbreviations of observed taxa (if needed) are as follows: Ablalon, Ablabesmyia longistyla; Arctlom, Arcteonais lomondi; Chaoflav, Chaoborus flavicans; Chirant, Chironomus anthracinus; Chirplu, C. plumosus; Chirsali, C. salinarius; PotaTubi, Potamothrix hammoniensis/Tubifex tubifex; Stylher, Stylodrilus heringianus; Spirfer, Spirosperma ferox; Limhoff, Limnodrilus hoffmeisteri; Lampiso, Lamprodrilus isoporus; Psammalb, Psammoryctides albicola; Protmor, Protanypus morio.; Microps, Micropsectra spp.;

where the specimens were considerably depleted in $\delta^{13} \mathrm{C}(\leq-32 \%)$ (Fig. 5).

\section{Discussion}

Here, we quantified for the first time the contribution of oxygen, temperature and sedimenting organic matter in controlling profundal macroinvertebrate assemblages in boreal lakes. The results highlight varying importance of the studied factors in regulating different aspects (species composition, diversity, abundance and ecological quality metric) of profundal communities. This study also confirms the earlier postulations that profundal macroinvertebrate assemblages are driven by a complex gradient integrating many inter-related environmental factors such as hypolimnetic temperature, oxygen and availability of sedimenting organic matter (e.g. Brodersen \& Anderson, 2002).

Our results agree with the general consensus that sedimenting organic matter is a strong driver of
Tanyspp, Tanytarsus spp.; Paranig, Paracladopelma nigritula; Sticros, Stictochironomus rosenschoeldi; Sergcor, Sergentia coracina; Hetapi, Heterotanytarsus apicalis; Hetsub, Heterotrissocladius subpilosus; Hetgri, Heterotrissocladius grimshawi; Mesothi, Mesocricotopus thienemanni; Monbat, Monodiamesa bathyphila; Stembaus, Stempellina bausei; Monoaff, Monoporeia affinis; Palqua, Pallasea quadrispinosa; Prooli, Prodiamesa olivacea; Polynub, Polypedilum nubeculosum; Polypul, Polypedilum pullum; Projacu, Propsilocerus jacuticus; Crypdef, Cryptochironomus defectus gr.; Mysrel, Mysis relicta

abundance and composition of profundal macroinvertebrate communities (Graf, 1989; Johnson \& Wiederholm, 1992; Goedkoop \& Johnson, 1996). SOM availability and quality had apparent contribution to the regulation community composition and biomass, whereas oxygen availability and temperature seemed to be the key predictors of Shannon diversity and Benthic Quality Index, respectively. The relationship between benthic species diversity and oxygen availability is widely evident in marine (Levin \& Gage, 1998), lentic (Cowell et al., 1987) and lotic (Dodds \& Welch, 2000) environments. In boreal lakes, temporary hypolimnetic oxygen deficits are frequently met, particularly in small humic lakes (Fulthorpe \& Paloheimo, 1985), even in near pristine ones (Jyväsjärvi et al., 2009), and the profundal assemblages are restricted to a few taxa adapted to low oxygen concentration (e.g. Chironomus spp. and Chaoborus flavicans larvae). The variation of BQI was mostly accounted for by hypolimnetic temperature rather than oxygen conditions or SOM was perhaps surprising. 


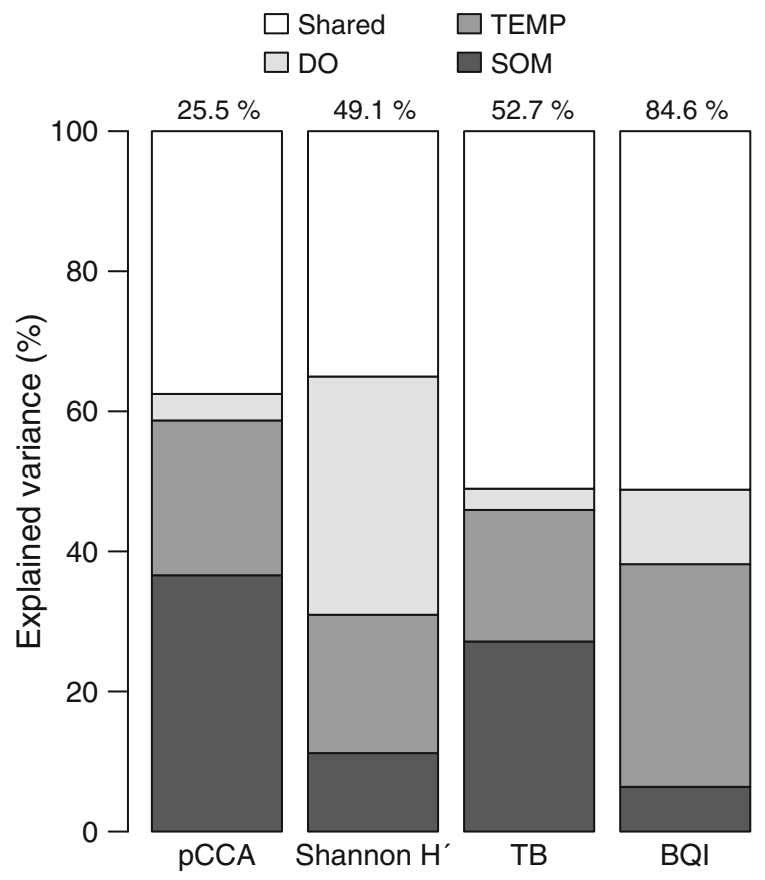

Fig. 2 The individual and shared proportions of variation in partial CCA, Shannon diversity $\left(H^{\prime}\right)$, total biomass (TB) and benthic quality index (BQI) explained by the measured variable groups. Proportion of total explained variation is indicated above each bar

However, it is consistent with our previous findings (Jyväsjärvi et al., 2009) of a strong correlation between BQI and lake depth among minimally disturbed lakes because variation in hypolimnetic temperature is closely associated with lake depth (in this study, $r=0.69$; see also Ottosson \& Abrahamsson, 1998).
Our results indicated that, in accordance with the general assumption (Saether, 1979; Jónasson, 2004), sedimenting organic matter is more important in structuring macroinvertebrate assemblages of oligotrophic sites, among which community variation in these sites was strongly attributed to input of SOM. This suggests that communities in oligotrophic basins are limited by SOM, whereas eutrophic basins might provide food resources, including food items other than SOM (e.g. bacteria, see Johnson et al., 1989), ad libitum, and there some other factors (e.g. oxygen availability) more strongly govern the community structure.

To our knowledge, this is the first work studying relationships of SOM and profundal macroinvertebrate community structure among a large number of lake basins. Similar sediment trap designs in relation to benthic fauna have been conducted only for individual lakes (Lang \& Hutter, 1982; Goedkoop \& Johnson, 1996), whereas among-lake relationships of macroinvertebrate fauna and sediment characteristics sampled by different methods have been studied only in the sublittoral zone by Vos et al. (2004). We decided to conduct sediment trapping during early autumn on the basis of the results of preliminary monthly monitoring of SOM (July-October). According to those data (not presented here), macroinvertebrate community composition was most closely related to SOM collected during August-October. Second, this period represents autumnal overturn of dimictic lakes with a typical sedimentation pulse (Bloesch, 2004). Third, in contrast to mid-summer, all chironomid taxa should then occur in lake sediment and be matured enough to be identifiable.

Table 5 Results of multiple linear regressions for macroinvertebrate metrics

\begin{tabular}{|c|c|c|c|c|c|}
\hline Macroinvertebrate metric & Predictor variable & $\beta$ & $t$ & AIC & Cum. $R^{2}$ \\
\hline \multirow[t]{3}{*}{ Shannon index } & Intercept & -1.570 & -2.274 & & \\
\hline & Temperature & 1.674 & 2.914 & 40.826 & 0.180 \\
\hline & Dissolved oxygen & 1.269 & 3.234 & 33.894 & 0.436 \\
\hline \multirow[t]{4}{*}{ Benthic Quality Index } & Intercept & 5.937 & 6.030 & & \\
\hline & Temperature & -4.828 & -5.615 & 51.335 & 0.622 \\
\hline & Dissolved oxygen & 2.111 & 4.095 & 40.625 & 0.798 \\
\hline & SOM (PC 1) & 1.406 & 2.463 & 38.282 & 0.844 \\
\hline \multirow[t]{3}{*}{ Total biomass } & Intercept & 0.263 & 6.084 & & \\
\hline & SOM (PC 1) & -0.916 & -4.154 & 0.185 & 0.418 \\
\hline & TEMP & 0.347 & 2.030 & -1.285 & 0.507 \\
\hline
\end{tabular}


- Eu-/mesotrophic basin $\quad$-.o.. Oligotrophic basin
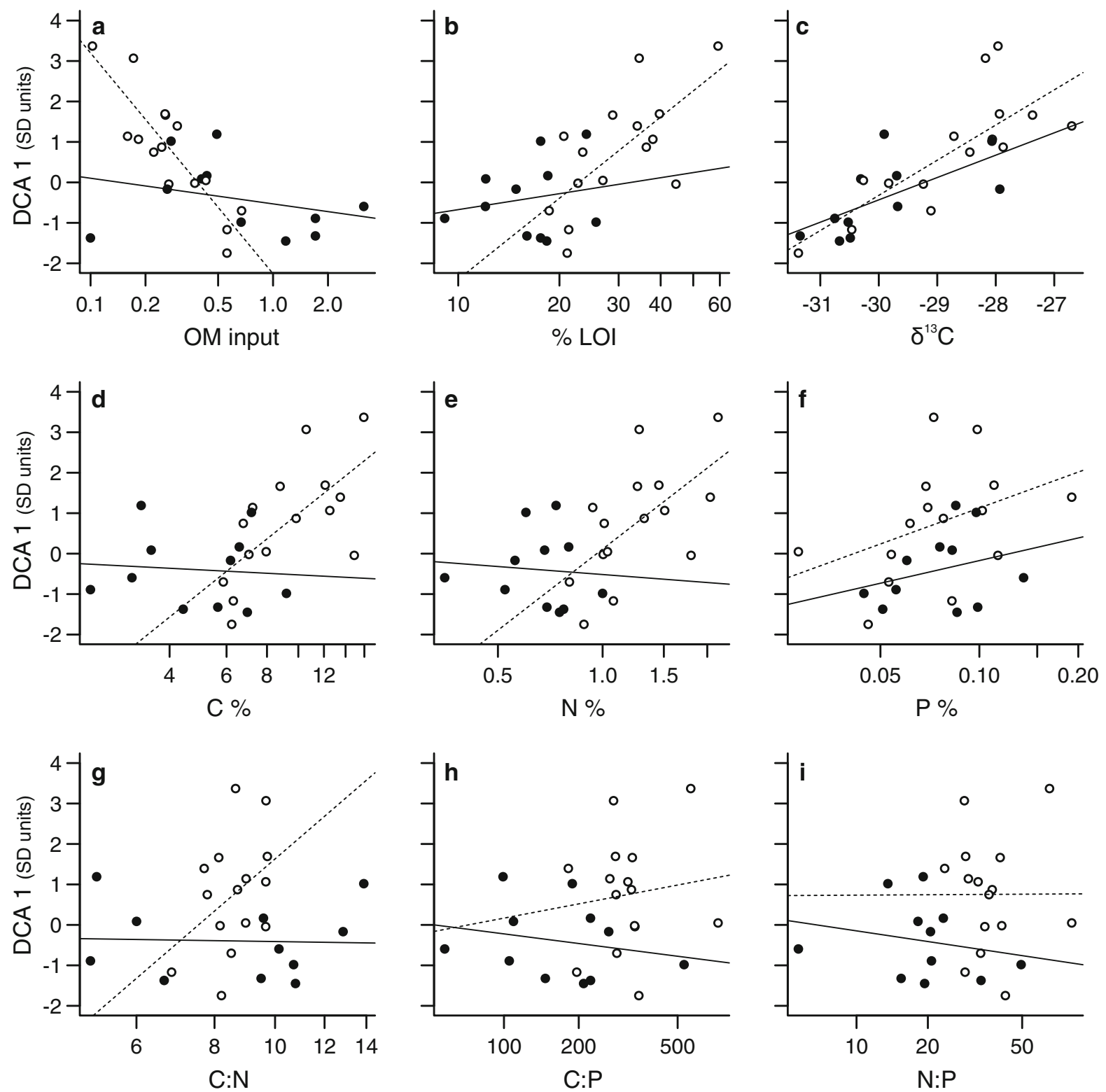

Fig. 3 Relationships between mean organic matter input, \% LOI and $\delta^{13} \mathrm{C}$ values $(\mathbf{a}-\mathbf{c})$, elemental contents $(\mathbf{d}-\mathbf{f})$ and stoichiometric ratios $(\mathbf{g}-\mathbf{i})$ of the sedimenting organic matter and site scores of the first DCA axis (i.e. measure of the community composition). Dots and solid regression lines denote the meso-

We had to extend the deployment period due to very low sedimentation rates in some ultraoligotrophic lakes basins (see Table 2). Consequently, some bacterial degradation of the collected material might have occurred inside the collector tubes. However, this potential qualification was not actually supported by and eutrophic (TP $>10 \mu \mathrm{g}^{-1}$ ) sites, whereas the white circles and dashed regression lines represent the oligotrophic sites $\left(\mathrm{TP}<10 \mu \mathrm{g}^{-1}\right)$. Lines show the fits of simple linear regression models

the supplementary data from Lake Jyväsjärvi main basin (Jyv3), where virtually no differences in elemental content or $\delta^{13} \mathrm{C}$ values were observed between the samples collected after 14 or 28 days. Also, exclusion of zooplankton and other invertebrates using a $250-\mu \mathrm{m}$ sieve removed only larger individuals, 
Table 6 Linear model results for the relationships of DCA 1 axis scores with trophic class, SOM variables and their interactions

\begin{tabular}{|c|c|c|}
\hline \multirow[t]{2}{*}{ Predictor } & \multicolumn{2}{|c|}{ DCA axis scores } \\
\hline & $t$ & $P$ \\
\hline OM input & -5.620 & $<0.001$ \\
\hline Trophic class & 0.741 & 0.467 \\
\hline Trophic class $\times \mathrm{OM}$ input & 4.684 & $<0.001$ \\
\hline LOI & 2.523 & 0.019 \\
\hline Trophic class & -0.371 & 0.714 \\
\hline Trophic class $\times$ LOI & -1.671 & 0.109 \\
\hline$\delta^{13} \mathrm{C}$ & 4.570 & $<0.001$ \\
\hline Trophic class & -0.878 & 0.389 \\
\hline Trophic class $\times \delta^{13} \mathrm{C}$ & -1.019 & 0.319 \\
\hline $\mathrm{C} \%$ & 2.167 & 0.041 \\
\hline Trophic class & -0.940 & 0.357 \\
\hline Trophic class $\times \mathrm{C} \%$ & -2.519 & 0.020 \\
\hline $\mathrm{N} \%$ & 1.040 & 0.310 \\
\hline Trophic class & -0.888 & 0.384 \\
\hline Trophic class $\times \mathrm{N} \%$ & -1.583 & 0.128 \\
\hline $\mathrm{P} \%$ & 1.220 & 0.235 \\
\hline Trophic class & -2.247 & 0.035 \\
\hline Trophic class $\times \mathrm{P} \%$ & -0.257 & 0.799 \\
\hline $\mathrm{C}: \mathrm{N}$ & 1.684 & 0.106 \\
\hline Trophic class & -2.451 & 0.023 \\
\hline Trophic class $\times \mathrm{C}: \mathrm{N}$ & -1.731 & 0.097 \\
\hline $\mathrm{C}: \mathrm{P}$ & 0.135 & 0.894 \\
\hline Trophic class & -1.813 & 0.084 \\
\hline Trophic class $\times \mathrm{C}: \mathrm{P}$ & -0.709 & 0.486 \\
\hline $\mathrm{N}: \mathrm{P}$ & -0.295 & 0.771 \\
\hline Trophic class & -1.980 & 0.060 \\
\hline Trophic class $\times \mathrm{N}: \mathrm{P}$ & -0.324 & 0.749 \\
\hline
\end{tabular}

whereas some smaller taxa (e.g. rotifers) may have remained in the samples, thus possibly altering the properties of the collected material. Overall, the contribution of the above mentioned potential sources of uncertainty to the quality of the SOM data and the following community patterns are difficult to estimate precisely and would require further research (see Bloesch \& Burns, 1980). Nonetheless, we argue that these uncertainties are most likely to weaken the pelagic-benthic relationships so that the observed patterns could have been even more evident for data lacking those weaknesses.

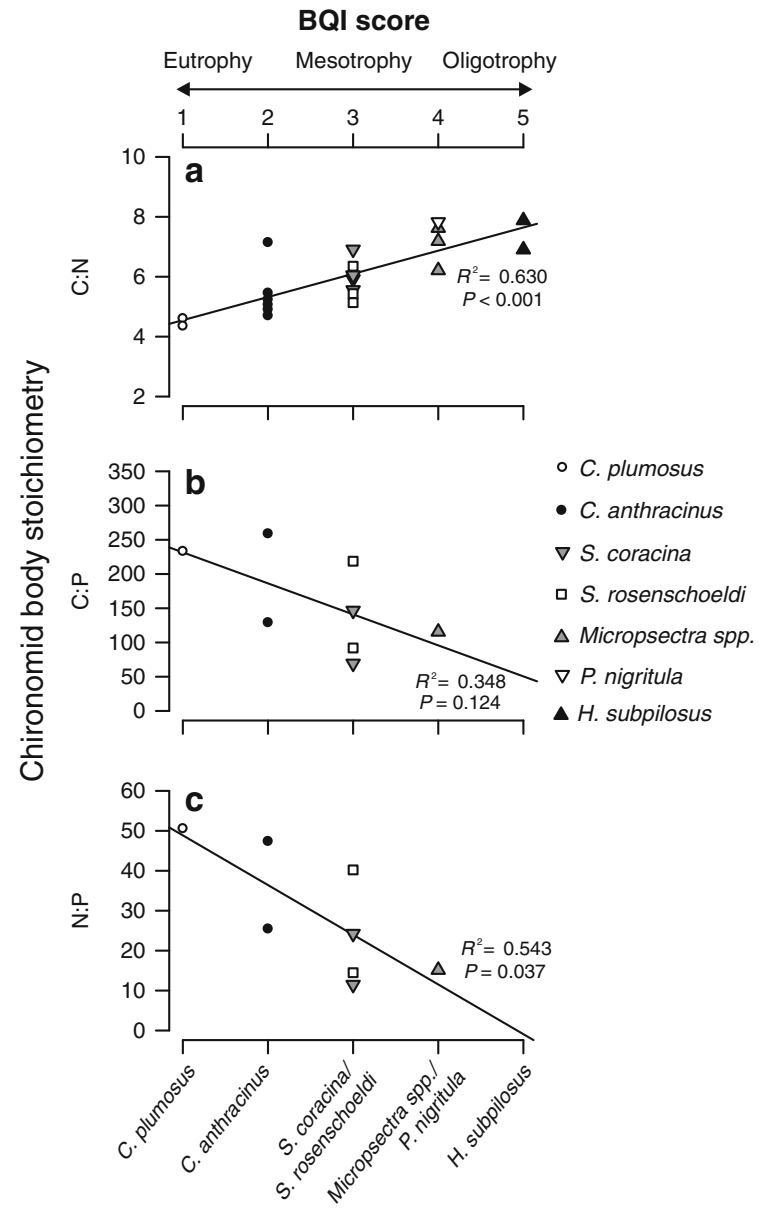

Fig. 4 Relationships between larval C:N (a), C:P (b) and N:P ratios (c) and 'trophic preference' values (benthic quality index scores) for seven BQI chironomid indicator taxa. Fitted regression lines and coefficients of determination $\left(R^{2}\right)$ and corresponding $P$ values are displayed. Also the direction of the trophic status gradient parallel to horizontal axis is shown above

Although the data are limited, our chironomid larval analyses suggest some intriguing relationships between chironomid stoichiometry and their ecological niches. Stoichiometric ratios differed markedly among the studied chironomid indicator taxa. Furthermore, we found correlations between elemental ratios ( $\mathrm{C}: \mathrm{N}, \mathrm{C}: \mathrm{P}$ and $\mathrm{N}: \mathrm{P}$ ) and the $\mathrm{BQI}$ score (i.e. environmental tolerance) of the corresponding taxa. These results are partially concordant with those recently reported by Dang et al. (2009) of evident relationships between elemental stoichiometry of stream macroinvertebrates and their tolerance to organic pollution (US Stream Rapid Bioassessment and BMWP scores). In both studies, there was a 


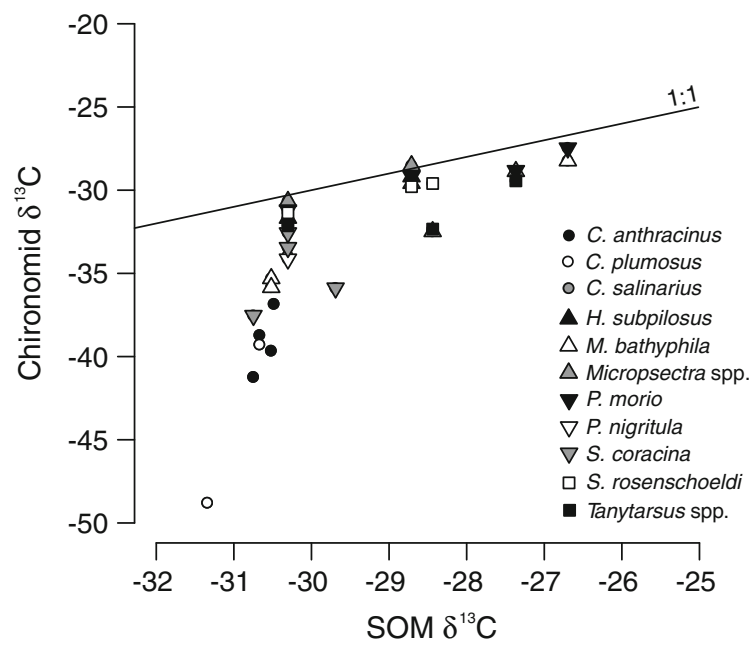

Fig. 5 Relationship between $\delta^{13} \mathrm{C}$ values of sedimenting organic matter (SOM) and chironomid larvae. Solid line represents 1:1 relationship

strong positive relationship between $\mathrm{C}: \mathrm{N}$ ratio and the sensitivity to nutrient/organic pollution of macroinverterbrate taxa. However, in contrast to those of Dang et al. (2009), our results suggest a negative relationship between chironomid $\mathrm{C}: \mathrm{P}$ and $\mathrm{N}: \mathrm{P}$ ratios and $\mathrm{BQI}$ scores. Given that literature suggests low algal $\mathrm{C}$ :nutrient ratios in nutrientenriched systems (Tilman, 1982; Kilham, 1990; Huisman \& Weissing, 1995), the observed pattern is counterintuitive.

There are various likely explanations for the peculiar variance of stoichiometric ratios among the studied profundal chironomid taxa. The chironomid taxa inhabiting eutrophic sites, C. plumosus in particular, are adapted to oxygen-poor conditions partly due to high haemoglobin concentration (Weber, 1980; Int Panis et al., 1995), whereas the taxa generally considered intolerant to anoxia (Orthocladiinae) are largely lacking haemoglobin (Cranston, 1988). Varying concentrations of nitrogen-rich haemoglobin protein might thus result in the correlations between trophic preference of chironomid taxa and both $\mathrm{N}$ content and $\mathrm{C}: \mathrm{N}$ ratio, but not with $\mathrm{P}$. The studied taxa vary markedly in their body size $(5-25 \mathrm{~mm})$ and the size is related to their indicator (BQI) value $(r=-0.89)$ and thus to body $\mathrm{N}: \mathrm{P}$ stoichiometry $(r=0.59)$. Elser et al. (2006) presented a prediction scheme in which small organisms are presumed to have a high characteristic growth rate (Peters, 1983), which requires more efficient allocation of phosphorus-rich ribonucleic acid (RNA) compared to larger organisms.
Therefore, $\mathrm{C}: \mathrm{P}$ and $\mathrm{N}: \mathrm{P}$ are generally positively related to body size, which is consistent with the pattern observed in this study. The relationships between chironomid body stoichiometry and trophic preference also correspond with previously reported alteration of SOM C:N:P stoichiometry during the sedimentation process; deeper basins provide nitrogen-poor but phosphorus-rich sedimenting organic material (Gálvez et al., 1991; Andersen \& Jensen, 1992; Garcia-Ruiz et al., 2001). Even though our SOM data lacked vertical monitoring and within-lake data did not support this pattern, the chironomid data suggest that profundal taxa with differing ecological niches differently assimilate the key macroelements, either due to differences in feeding habits (Johnson, 1987; Goedkoop et al., 1998), to selective feeding (Johnson et al., 1989) or to varying stoichiometric requirements relative to the available food.

Carbon stable isotopic signatures of chironomid larvae were depleted in comparison to $\delta^{13} \mathrm{C}$ measured from SOM, as is generally the case (Jones et al., 2008) and this presumably reflects selective ingestion and/or assimilation of available organic matter. However, this relative depletion was particularly evident at sites with low SOM $\delta^{13} \mathrm{C}$ and high abundances of Chironomus anthracinus and C. plumosus larvae, which could reflect greater utilization of methane-oxidizing bacteria as a food source-a phenomenon usually occurring with low oxygen concentrations (Jones et al., 2008; Jones \& Grey, 2011). In addition to the two Chironomus species, the carbon isotope signature of two more mesotrophic species (Sergentia coracina and Monodiamesa bathyphila [Kieffer]) deviated appreciably from those measured from the SOM. In contrast, $\delta^{13} \mathrm{C}$ of the taxa preferring large and deep oligotrophic lakes (H. subpilosus, Protanypus morio [Zetterstedt], Micropsectra spp.) were closer to SOM $\delta^{13} \mathrm{C}$ suggesting more direct reliance on SOM for these taxa.

Our data suggested a strong relationship between profundal macroinvertebrate community composition and carbon stable isotope signal $\left(\delta^{13} \mathrm{C}\right)$ of SOM. In contrast to the other parameters measured from the SOM, $\delta^{13} \mathrm{C}$ correlated strongly with community variation irrespective of the trophic status of the basin. When $\delta^{13} \mathrm{C}$ was added to the CCA model, it showed a considerable contribution (17\%) to the total explained variance which increased by an additional $5 \%$. The $\delta^{13} \mathrm{C}$ of SOM varied between $-31.4 \%$ in eutrophic basins and $-26.7 \%$ in oligotrophic sites and initially suggested that the SOM in sites with eutrophic fauna is 
originating primarily from the pelagic algal production $\left(\delta^{13} \mathrm{C}\right.$ around $\left.-32 \%\right)$, whereas benthic algae $\left(\delta^{13} \mathrm{C}\right.$ around $-26 \%$ ) might serve as the predominant food source for the benthic communities of oligotrophic basins (see France, 1995). Recently, von Wachenfeldt \& Tranvik (2008) measured similarly light isotopic signatures of sedimenting organic carbon $(\sim-27 \%)$ and concluded that the majority of the sedimenting organic matter was of allochthonous origin rather than produced in a lake per se. It is thus also possible that the more enriched carbon isotope signatures of SOM in this study indicate a stronger relative contribution of terrestrial organic material in driving the profundal macroinvertebrate communities in more oligotrophic lakes. However, given the generally low $\mathrm{C}: \mathrm{N}$ ratios $(<10)$ of SOM, particularly in those sites with oligotrophic fauna, it seems evident that organic matter is indeed of autochthonous origin (Håkanson \& Jansson, 1983; Meyers \& Teranes, 2001) and some alternative mechanisms control the $\delta^{13} \mathrm{C}$ variation of SOM.

For instance, the variation of SOM carbon isotope signatures might be a consequence of differences in phytoplankton communities. Vuorio et al. (2006) assessed $\delta^{13} \mathrm{C}$ differences among pelagic phytoplankton taxa from four Finnish lakes. Diatom $\delta^{13} \mathrm{C}$ varied between -30.6 and $-26.6 \%$ thus overlapping with the terrestrial $\delta^{13} \mathrm{C}$ signal, whereas e.g. chrysophytes had a more negative isotopic signature $(<-31.3 \%$ ). Diatoms are generally rich in polyunsaturated fatty acids (Dunstan et al., 1993) and are thus a high-quality food source for profundal macroinvertebrates in both marine (Lopez \& Levinton, 1987) and freshwater environments (Johnson \& Wiederholm, 1992). Veefkind (2003) reported strong correlation between carbon isotopic signature of marine particulate organic matter (POM) and highquality fatty acid abundance $(16: 2 n-4)$, indicating that $\delta^{13} \mathrm{C}$ might be used as a proxy of SOM quality. If similar associations apply in boreal lakes, it is possible that the fatty acid composition of SOM may contribute to structuring profundal macroinvertebrate assemblages and future studies incorporating macroinvertebrate community ecology and food resource fatty acid analytics might provide insight into this issue.

\section{Conclusions}

Here, we provided the first quantitative estimation of the relative importance of sedimenting organic matter, hypolimnetic oxygen and temperature in structuring the profundal macroinvertebrate assemblages of boreal lakes. The results based on a representative selection of boreal lake basins suggest a potential contribution of SOM in governing the variation of biomass and community composition in particular and, furthermore, that this pelagic-benthic coupling is more evident in oligotrophic lakes. Our study also validate the general but poorly empirically demonstrated consensus that profundal assemblages are controlled by sedimenting organic matter, oxygen and temperature in concert rather than any of these factors alone. Additional stoichiometric and stable isotope analyses of the variety of profundal chironomid taxa indicated among-taxa differences in body stoichiometry and in utilization of SOM, respectively. The origin of SOM, as inferred from carbon stable isotope signals, seemed of importance in structuring profundal macroinverterbrate assemblages, but confirming the actual mechanisms behind this pattern requires further studies incorporating additional qualitative measures of sedimenting organic matter.

Acknowledgments The authors are grateful to following people for their assistance in the field or laboratory: Tuula Sinisalo, Helena Jäntti, Virve Kustula, Olli Nousiainen, Pertti Saaristo, Lauri Arvola, Kalevi Salonen, Mika Nieminen and Timo Ruokonen. Special thanks to Oulun Verkkopalloseura and Puijo Tennis Team for those tens of empty tennis ball tubes we needed. Financial support for this study was provided by the Maj and Tor Nessling Foundation, the VALUE Finnish Graduate School and the FUNCDYN program of the European Science Foundation.

\section{References}

Andersen, F. O. \& H. S. Jensen, 1992. Regeneration of inorganic phosphorus and nitrogen from decomposition of seston in a freshwater sediment. Hydrobiologia 228: 71-81.

Blais, J. M. \& J. Kalff, 1995. The influence of lake morphometry on sediment focusing. Limnology and Oceanography 40 : 582-588.

Bloesch, J., 2004. Sedimentation and lake sediment formation. In O'Sullivan, P. E. \& C. S. Reynolds (eds), The Lakes Handbook. Limnology and Limnetic Ecology. Blackwell Publishing, Malden: 197-229.

Bloesch, J. \& N. M. Burns, 1980. A critical review of sedimentation trap technique. Schweizerische Zeitschrift für Hydrologie 42: 15-55.

Borcard, D., P. Legendre \& P. Drapeau, 1992. Partialling out the spatial component of ecological variation. Ecology 73 : 1045-1055.

Brinkhurst, R. O., 1974. The Benthos of Lakes. Blackburn Press, Caldwell. 
Brodersen, K. P. \& N. J. Anderson, 2002. Distribution of chironomids (Diptera) in low arctic West Greenland lakes: trophic conditions, temperature and environmental reconstruction. Freshwater Biology 47: 1137-1157.

Brodersen, K. P. \& R. Quinlan, 2006. Midges as palaeoindicators of lake productivity, eutrophication and hypolimnetic oxygen. Quaternary Science Reviews 25: 1995-2012.

Brooks, S. J., P. G. Langdon \& O. Heiri, 2007. The Identification and Use of Palearctic Chironomidae Larvae in Palaeoecology. QRA Technical Guide No. 10. Quaternary Research Association, London.

Brundin, L., 1951. The relation of $\mathrm{O}_{2}$-microstratification at the mud surface to the ecology of the profundal bottom fauna. Institute of Fresh-water Research, Drottningholm 32: 32-43.

Cowell, B. C., C. J. Dawes, W. E. Gardiner \& S. E. Scheda, 1987. The influence of whole lake aeration on the limnology of a hypereutrophic lake in central Florida. Hydrobiologia 148: 3-24.

Cranston, P., 1988. Allergens of non-biting midges (Diptera: Chironomidae): a systematic survey of chironomid haemoglobins. Medical and Veterinary Entomology 2: 117-127.

Dang, C. K., S. Harrison, M. M. Sturt, P. S. Giller \& M. A. Jansen, 2009. Is the elemental composition of stream invertebrates a determinant of tolerance to organic pollution. Journal of the North American Benthological Society 28: 778-784.

Dinsmore, W. P., G. J. Scrimgeour \& E. E. Prepas, 1999. Empirical relationships between profundal macroinvertebrate biomass and environmental variables in boreal lakes of Alberta, Canada. Freshwater Biology 41: 91-100.

Dodds, W. K. \& E. B. Welch, 2000. Establishing nutrient criteria in streams. Journal of the North American Benthological Society 19: 186-196.

Dunstan, G. A., J. K. Volkman, S. M. Barrett, J.-M. Leroia \& S. W. Jeffrey, 1993. Essential polyunsaturated fatty acids from 14 species of diatom (Bacillariophyceae). Phytochemistry 35 : $155-161$.

Elser, J. J., 2006. Biological stoichiometry: a chemical bridge between ecosystem, ecology and evolutionary biology. American Naturalist 168: 25-35.

Elser, J. J., D. R. Dobberfuhl, N. A. MacKay \& J. H. Schampel, 2006. Organism size, life history and N:P stoichiometry. BioScience 46: 674-684.

European Commission, 2000. Directive 2000/60/EC 2000 Establishing a Framework for Community Action in the Field of Water Policy. Official Journal of the European Communities L 327/1: 1-72.

France, R. L., 1995. Carbon-13 enrichment in benthic compared to planktonic algae: foodweb implications. Marine Ecology Progress Series 124: 307-312.

Fulthorpe, R. \& J. Paloheimo, 1985. Hypolimnetic oxygen consumption in small lakes. Canadian Journal of Fisheries and Aquatic Sciences 42: 1493-1500.

Gálvez, J. A., F. X. Niell \& L. Lucena, 1991. C:N:P ratio of settling seston in a eutrophic reservoir. Verhandlungen Internationale Vereinigung für Theoretische und Angewandte Limnologie 24: 1390-1395.

Garcia-Ruiz, R., G. Parra, F. Guerrero \& J. Lucena, 2001. Sedimentation of phosphorus fractions and temporal variation in the $\mathrm{C}: \mathrm{P}$ ratio in La Concepcion reservoir, southern
Spain. New Zealand Journal of Marine and Freshwater Research 35: 711-723.

Goedkoop, W. \& R. K. Johnson, 1996. Pelagic-benthic coupling: profundal benthic community response to spring diatom deposition in mesotrophic Lake Erken. Limnology and Oceanography 41: 636-647.

Goedkoop, W., L. Sonesten, H. Markensten \& G. Ahlgren, 1998. Fatty acid biomarkers show dietary differences between dominant chironomid taxa in Lake Erken. Freshwater Biology 40: 135-143.

Graf, G., 1989. Benthic-pelagic coupling in a deep-sea benthic community. Nature 341: 437-439.

Grasshoff, K., M. Ehrhardt \& K. Kremling, 1983. Methods of Seawater Analysis, 2nd ed. Verlag Chemie, Weinheim.

Håkanson, L., 1976. A bottom sediment trap for recent sedimentary deposits. Limnology and Oceanography 21: 125-133.

Håkanson, L., 1981. A Manual of Lake Morphometry. Springer, Berlin.

Håkanson, L. \& M. Jansson, 1983. Principles of Lake Sedimentology. Springer, Berlin.

Hill, M. O. \& H. G. Gauch, 1980. Detrended correspondence analysis: an improved ordination technique. Vegetatio 42 : 47-58.

Hilton, J., J. Lishman \& P. Allen, 1986. The dominant processes of sediment distribution and focusing in a small, eutrophic, monomictic lake. Limnology and Oceanography 31: 125-133.

Hudson, J. J. \& W. D. Taylor, 2005. Phosphorus sedimentation during stratification in two small lakes. Archiv für Hydrobiologie 162: 309-325.

Huisman, J. \& F. J. Weissing, 1995. Competition for nutrients and light in a mixed water column: a theoretical analysis. American Naturalist 146: 536-564.

Hynynen, J., A. Palomäki, H. Veijola, J. J. Meriläinen, P. Bagge, P. Manninen, A. Ustinov \& S. Bibiceanu, 1999. Planktonic and zoobenthic communities in an oligotrophic, boreal lake inhabited by an endemic and endangered seal population. Boreal Environment Research 4: 145-161.

Int Panis, L., B. Goddeeris \& R. F. Verheyen, 1995. The hemoglobin concentration of Chironomus cf. plumosus L. (Diptera: Chironomidae) larvae from two lentic habitats. Aquatic Ecology 29: 1-4.

Int Panis, L., B. Goddeeris \& R. F. Verheyen, 1996. On the spatial distribution and respiratory environment of benthic macroinvertebrates in ponds. Hydrobiologia 319: 131-136.

Jackson, D. A., 1993. Stopping rules in principal components analysis: a comparison of heuristical and statistical approaches. Ecology 74: 2204-2214.

Jewell, W. J. \& P. L. McCarty, 1971. Aerobic decomposition of algae. Environmental Science \& Technology 5: 1023-1031.

Johnson, R. K., 1987. Seasonal variation in diet of Chironomus plumosus (L.) and C. anthracinus Zett. (Diptera: Chironomidae) in mesotrophic Lake Erken. Freshwater Biology 17: 525-532.

Johnson, R. K. \& T. Wiederholm, 1989. Classification and ordination of profundal macroinvertebrate communities in nutrient poor, oligo-mesohumic lakes in relation to environmental data. Freshwater Biology 21: 375-386.

Johnson, R. K. \& T. Wiederholm, 1992. Pelagic-benthic coupling - the importance of diatom interannual variability for 
population oscillations of Monoporeia affinis. Limnology and Oceanography 37: 1596-1607.

Johnson, R. K., B. Boström \& W. van de Bund, 1989. Interactions between Chironomus plumosus (L.) and the microbial community in surficial sediments of a shallow, eutrophic lake. Limnology and Oceanography 34: 992-1003.

Jónasson, P. M., 2004. Benthic invertebrates. In O'Sullivan, P. E. \& C. S. Reynolds (eds), The Lakes Handbook. Limnology and Limnetic Ecology. Blackwell Publishing, Malden: 341-416.

Jones, R. I. \& J. Grey, 2011. Biogenic methane in freshwater food webs. Freshwater Biology 56: 213-229.

Jones, R. I., C. E. Carter, A. Kelly, S. Ward, D. J. Kelly \& J. Grey, 2008. Widespread contribution of methane cycle bacteria to the diets of lake profundal chironomid larvae. Ecology 89: 857-864.

Jyväsjärvi, J., K. T. Tolonen \& H. Hämäläinen, 2009. Natural variation of profundal macroinvertebrate communities in boreal lakes is related to lake morphometry: implications for bioassessment. Canadian Journal of Fisheries and Aquatic Sciences 66: 589-601.

Jyväsjärvi, J., J. Nyblom \& H. Hämäläinen, 2010. Palaeolimnological validation of estimated reference values for a lake profundal macroinvertebrate metric (benthic quality index). Journal of Paleolimnology 44: 253-264.

Jyväsjärvi, J., J. Aroviita \& H. Hämäläinen, 2012. Performance of profundal macroinvertebrate assessment in boreal lakes depends on lake depth. Fundamental and Applied Limnology 180: 91-100.

Kamp-Nielsen, L. \& B. T. Hargrave, 1978. Influence of bathymetry on sediment focusing in Lake Esrom. Verhandlungen Internationale Vereinigung für Theoretische und Angewandte Limnologie 20: 714-719.

Kansanen, P. H., J. Aho \& L. Paasivirta, 1984. Testing the benthic lake type concept based on chironomid associations in some Finnish lakes using multivariate statistical methods. Annales Zoologici Fennici 21: 55-76.

Kilham, S. S., 1990. Relationship of phytoplankton and nutrients to stoichiometric measures. In Tilzer, M. M. \& C. Serruya (eds), Large Lakes: Ecological Structure and Function. Springer, Berlin: 403-414.

Lang, C. \& P. Hutter, 1982. Structure, diversity and stability of two oligochaete communities according to sedimentary inputs in Lake Geneva (Switzerland). Aquatic Science 43: 265-276.

Legendre, P. \& L. Legendre, 1998. Numerical Ecology, 2nd ed. Elsevier Science BV, Amsterdam.

Levin, L. A. \& J. D. Gage, 1998. Relationships between oxygen, organic matter and the diversity of bathyal macrofauna. Deep Sea Research Part II: Topical Studies in Oceanography 45: 129-163.

Likens, G. E. \& M. B. Davis, 1975. Post-glacial history of Mirror Lake and its watershed in New Hampshire, U.S.A.: an initial report. Verhandlungen Internationale Vereinigung für Theoretische und Angewandte Limnologie 19: 982-993.

Lindegaard, C., 1994. The role of zoobenthos in energy flow in two shallow lakes. Hydrobiologia 275-276: 313-322.

Lopez, G. R. \& J. S. Levinton, 1987. Ecology of deposit-feeding animals in marine sediments. Quarterly Review of Biology 62: $235-260$.
Mackereth, F. J. H., J. Heron \& J. F. Talling, 1978. Water analysis: some revised methods for limnologists. Scientific Publication No. 36. Freshwater Biological Association, UK

Meyers, P. A. \& J. L. Teranes, 2001. Sediment organic matter. In Last, W. M. \& J. P. Smol (eds), Tracking Environmental Change Using Lake Sediments, Physical and Chemical Methods, Vol. 2. Kluwer Academic Publishers, Dordrecht: 239-269.

Molongoski, J. J. \& M. J. Klug, 1980. Quantification and characterization of sedimenting particulate organic matter in a shallow hypereutrophic lake. Freshwater Biology 10: 497-506.

OECD, 1982. Eutrophication of Waters. Monitoring Assessment and Control. Final Report. OECD Cooperative Programme on Monitoring of Inland Waters (Eutrophication Control), Environment Directorate, OECD, Paris.

Økland, R. H. \& O. Eilertsen, 1994. Canonical correspondence analysis with variation partitioning: some comments and an application. Journal of Vegetation Science 5: 117-126.

Oksanen J., R. Kindt, P. Legendre, B. O'Hara, G. L. Simpson, P. Solymos, M. H. H. Stevens \& H. Wagner, 2008. vegan: Community Ecology Package. R package version 1.15-1. http://vegan.r-forge.r-project.org/.

Ottosson, F. \& O. Abrahamsson, 1998. Presentation and analysis of a model simulating epilimnetic and hypolimnetic temperatures in lakes. Ecological Modelling 110: 233-253.

Peters, R. H., 1983. Ecological Implications of Body Size. Cambridge University Press, Cambridge.

R Development Core Team, 2008. R: a language and environment for statistical computing. R Foundation for Statistical Computing. http://www.r-project.org.

Rask, M., K.-M. Vuori, H. Hämäläinen, M. Järvinen, S. Hellsten, H. Mykrä, L. Arvola, J. Ruuhijärvi, J. Jyväsjärvi, I. Kolari, M. Olin, E. Salonen \& P. Valkeajärvi, 2011. Ecological classification of large lakes in Finland: comparison of classification approaches using multiple quality elements. Hydrobiologia 660: 37-47.

Rasmussen, J. B. \& J. Kalff, 1987. Empirical models for zoobenthic biomass in lakes. Canadian Journal of Fisheries and Aquatic Sciences 44: 990-1001.

Real, M. \& N. Prat, 1992. Factors influencing the distribution of chironomids and oligochaetes in profundal areas of Spanish reservoirs. Aquatic Ecology 26: 405-410.

Real, M., M. Rieradevall \& N. Prat, 2000. Chironomus species (Diptera: Chironomidae) in the profundal benthos of Spanish reservoirs and lakes: factors affecting distribution patterns. Freshwater Biology 43: 1-18.

Saether, O. A., 1979. Chironomid communities as water quality indicators. Holarctic Ecology 2: 65-74.

Schielzeth, H., 2010. Simple means to improve the interpretability of regression coefficients. Methods in Ecology and Evolution 1: 103-113.

Schindler, D., 1974. Eutrophication and recovery in experimental lakes: implications for lake management. Science 184: 897-899.

SFS, 1989. Standard no: 5076. Sampling of the bottom fauna on soft bottoms with an Ekman grab. The Finnish Standards Association, Helsinki.

Shannon, C. E. \& W. Weaver, 1949. The Mathematical Theory of Communication. University of Illinois, Chicago. 
Simola, H. \& L. Arvola, 2005. Lakes in northern Europe. In O'Sullivan, P. E. \& C. S. Reynolds (eds), The Lakes Handbook. Lake Restoration and Rehabilitation. Blackwell Publishing, Malden: 117-158.

Sterner, R. W. \& J. J. Elser, 2002. Ecological Stoichiometry: The Biology of Elements from Molecules to the Biosphere. Princeton University Press, Princeton.

Strickland, J. D. H. \& T. R. Parsons, 1972. A Practical Handbook of Seawater Analysis, 2nd ed. Fisheries Research Board of Canada, Ottawa.

ter Braak, C. J. F., 1986. Canonical correspondence analysis: a new eigenvector technique for multivariate direct gradient analysis. Ecology 67: 1167-1179.

ter Braak, C. J. F. \& I. C. Prentice, 1988. A theory of gradient analysis. Advances in Ecological Research 4: 235-282.

Thienemann, A., 1922. Die beiden Chironomusarten der Tiefenfauna der norddeutschen Seen. Ein hydrobiologisches Problem. Archiv für Hydrobiologie 13: 609-646.

Tilman, D., 1982. Resource Competition and Community Structure. Princeton University Press, Princeton.

Veefkind, R. J., 2003. Carbon isotope ratios and composition of fatty acids: Tags and trophic markers of pelagic organisms. $\mathrm{PhD}$ Thesis. University of Victoria.

Verneaux, V., J. Verneaux, A. Schmitt \& J. C. Lambert, 2004. Relationships of macrobenthos with dissolved oxygen and organic matter at the sediment-water interface in ten French lakes. Archiv für Hydrobiologie 160: 247-259.
Vollenweider, R. A., 1968. Scientific fundamentals of the eutrophication of lakes and flowing waters, with particular reference to nitrogen and phosphorus as factors in eutrophication. Technical Report. OECD.

von Wachenfeldt, E. \& L. J. Tranvik, 2008. Sedimentation in boreal lakes - the role of flocculation of allochthonous dissolved organic matter in the water column. Ecosystems 11: 803-814.

Vos, J. H., E. T. H. M. Peeters, R. Gylstra, M. H. S. Kraak \& W. Admiraal, 2004. Nutritional value of sediments for macroinvertebrate communities in shallow eutrophic waters. Archiv für Hydrobiologie 161: 469-487.

Vuorio, K., M. Meili \& J. Sarvala, 2006. Taxon-specific variation in the stable isotopic signatures $\left(\delta^{13} \mathrm{C}\right.$ and $\left.\delta^{15} \mathrm{~N}\right)$ of lake phytoplankton. Freshwater Biology 51: 807-822.

Weber, R. E., 1980. Functions of invertebrate hemoglobins with special reference to adaptations to environmental hypoxia. American Zoologist 20: 79-101.

Wetzel, R. G., 2001. Limnology. Lake and River Ecosystems, 3rd ed. Academic Press, London.

Wiederholm, T., 1980. Use of benthos in lake monitoring. Journal of the Water Pollution Control Federation 52: 537-547.

Wiederholm, T., 1983. Chironomidae of the Holarctic region. Keys and diagnoses. Part 1. Larvae. Entomologica Scandinavica Supplementum 19: 1-457. 